DIGITAL COMMONS
@ UNIVERSITY OF SOUTH FLORIDA

Volume 4

Issue 2 Volume 4.2 (Fall 2014)

\section{ABO: Interactive Journal for Women in the Arts, 1640-1830}

\title{
The Beautiful Soul in the Confessional: Crafting the Moral Self in Friederike Helene Unger's Confessions of a Beautiful Soul written by Herself
}

Michelle A. Reyes

University of Illinois at Chicago, mlinto2@uic.edu

Follow this and additional works at: https://digitalcommons.usf.edu/abo

Part of the German Literature Commons, and the Women's Studies Commons

\section{Recommended Citation}

Reyes, Michelle A. (2014) "The Beautiful Soul in the Confessional: Crafting the Moral Self in Friederike Helene Unger's Confessions of a Beautiful Soul written by Herself," ABO: Interactive Journal for Women in the Arts, 1640-1830: Vol.4: Iss.2, Article 1. http://dx.doi.org/10.5038/2157-7129.4.2.1

Available at: https://digitalcommons.usf.edu/abo/vol4/iss2/1

This Scholarship is brought to you for free and open access by Digital Commons @ University of South Florida. It has been accepted for inclusion in ABO: Interactive Journal for Women in the Arts, 1640-1830 by an authorized administrator of Digital Commons @ University of South Florida. For more information, please contact digitalcommons@usf.edu. 


\title{
The Beautiful Soul in the Confessional: Crafting the Moral Self in Friederike Helene Unger's Confessions of a Beautiful Soul written by Herself
}

\begin{abstract}
This article examines how Unger's Confessions of a Beautiful Soul written by Herself creates a new model of moral acquisition. This model finds its place between religious morality and moral performance, calling for the novel's protagonist, Mirabella, to cultivate a moral self through the spiritual practice of reading. Such a model still revolves around moral transformation, but it is no longer of her soul, but rather her thoughts; that is, Mirabella must first collect various depictions of morality from a wide scope of literature, then choose from these which ones she deems as of greatest importance to her, namely virginity and the control of the passions, and then apply these two concepts in great measure to her self. The proof of her successful cultivation is then evident in her physiognomy. This model is as new as it is radical; first, it provides an alternative to Goethe's model in his fictional autobiography, Confessions of a Beautiful Soul; second, it contains implications for Mirabella in terms of both gender and class; finally, it allows for a new form of moral authenticity during a time of growing artifice in late eighteenth-century Germany. Foucault's notions of self-cultivation in The Care of the Self, as well as the commentaries on physiognomy advanced in the works of Lavater and Winckelmann, provide the interpretive lens for this new model.
\end{abstract}

\section{Keywords}

The "Beautiful Soul", 18th-Century Autobiography, Unger, Goethe, Self-Cultivation, Morality

\section{Creative Commons License}

cc) $($ ) $\ominus$

This work is licensed under a Creative Commons Attribution-No Derivative Works 3.0 License. 
In eighteenth-century Germany, there was a significant shift in autobiographical writing from pietistic confessions to secular accounts of life lived. ${ }^{i}$ In this shift, the metaphysical concept of morality was replaced by emerging notions of moral performance. In regard to the former-the prototype of which is August Hermann Francke's Curriculum Vitae (Lebenslauf [1690/91]) — a person's innate being was a fundamental premise and the development of his or her being from immoral to moral was orchestrated through no other means than divine conversion. For the latter, the mere appearance of morality, now subjectively defined, was given greater precedence. However, as this article argues, this shift was not tectonic, but rather gradual. German autobiographies during this time give evidence to the exploration of a third model of moral acquisition, in which rhetorical, narrative and conceptual continuities between the religious and secular genres can be identified. In these writings, the emerging modern self does not replace the soul but rather incorporates it throughout its cultivation, thereby crafting a spiritually moral self.

Drawing from Michel Foucault's notion of self-cultivation in The Care of the Self (1986), this article considers how Mirabella, in Friederike Helene Unger's fictional autobiography Confessions of a Beautiful Soul written by Herself ${ }^{\mathrm{i}}$ (Bekenntnisse einer schönen Seele von ihr selbst geschrieben [1806]), cultivates a moral self through spiritual practices. In the Confessions, Mirabella is still concerned with moral transformation, but its nexus is no longer her soul, but rather her thoughts. That is, she must cultivate and then act out her own unique form of morality utilizing her individual spheres of knowledge; instead of gaining an understanding of a doctrinally-based morality, Mirabella intentionally removes herself from any religious authoritative voice so as to create her own subjective moral form. This she accomplishes by first collecting various definitions and depictions of morality from a wide scope of secular literature, then choosing from these which ones she deems as of greatest importance to her, namely virginity and the control of the passions, and then applying these two concepts in great measure to her self. It is this new approach that links Mirabella's confession with modern self-cultivation, the latter of which Foucault describes as "a set of practices whose goal is the possibility of thinking differently" (45); for if individuals are unable to separate themselves from the opinions of their traditional affiliations, they will take up a posture that Foucault found ridiculous, namely that they will continue to have others tell them what to do and how to think (Ibid.). Finally, in a reversion back to the religious triadic paradigm of body, mind and soul, Mirabella concludes her confessions with a discussion of her accompanying aesthetic arrangement, i.e., physical proof of her moral self, which she argues must be both tested and refined before her cultivation can be considered complete. 
Unger's Confessions is arguably crafted as a direct response to the fictional autobiography "Confessions of a Beautiful Soul" ("Bekenntnisse einer schönen Seele") in Book VI of Johann Wolfgang von Goethe's developmental novel, Wilhelm Meister's Apprenticeship (Wilhelm Meisters Lehrjahre [1796/96]), which describes the moral self-cultivation of an unnamed woman (the "beautiful soul"). This seemingly religious woman also seeks to gain the heralded virtue of pietism, i.e., morality, by rejecting the path of transformation through divine conversion and instead pursuing a more modern and secular form of development. The "beautiful soul" engages in intensive readings of one specific pietistic hymnal and, through her selections and applications of it, she claims to achieve chastity in its highest form. Thereafter, the "beautiful soul" recedes from society, believing that her moral perfection would be tainted, or threatened, by any form of human contact, be it the court, her pietistic (specifically Moravian) community or even her family. By the end of the "Confessions," she is utterly alone, yet in complete bliss, concluding that, "I follow my thoughts freely and do not know of either restrictions or remorse" ("Ich folge mit Freiheit meinen Gesinnungen und weiß so wenig von Einschränkung als von Reue" [HA 7:421]). ${ }^{\text {iii }}$

One of Unger's secondary purposes is to counter Goethe with a model of moral self-cultivation from a female perspective. There are several explicit differences between these two "beautiful souls," including the attitude that both of them have toward their own development; while Goethe's "beautiful soul" assumes a preexisting level of morality, in Unger's novel, Mirabella views her self as a tabula rasa, seeing her life's purpose as pursuing a long-term cultivation of both moral thought and behavior. More importantly, Goethe and Unger provide different methods for how their female protagonists should craft a moral self. Goethe sets up a model in which the "beautiful soul's" development is mediated by her male relatives, first by her fiancée and later by her uncle. Unger, conversely, gradually removes the male voice from her narrative, allowing Mirabella to gain a level of independence over her specifically female self. ${ }^{\text {iv }}$ Finally, the morality of Goethe's "beautiful soul" incorporates both religious and secular knowledge, while Mirabella chooses to craft her morality from secular constructs alone. It is no surprise then that feminist critics argue that Unger's novel should be read as a feminist revision of Goethe's "Confessions,", a revision which Goethe himself largely disapproved of. ${ }^{\mathrm{vi}}$

The Confessions is written in the form of three letters to Mirabella's male friend, Cäsar. Her first letter to him begins with a description of her self in its original state as an orphaned child. Her first words are, "Who my parents were, I cannot say; for I have never met them" "vii ("Wer meine Eltern gewesen sind, vermag ich nicht zu sagen; denn ich habe sie nie kennen gelernt" [3]). In beginning the story 
of her life as such, Mirabella creates an immediate disconnect from both biological ancestry and religious heritage. In doing so, her orphaned status metaphorically represents the phenomenon taking place around 1800, in which individuals were beginning to become detached from the socio-familial framework within which their lives used to unfold, including the attitudes, practices and forms of existence that these affiliations affirmed (Foucault 41). At the same time, Mirabella the orphan directly challenges the concept of the family - in this first paragraph of her letter, she concludes by stating, "My existence was the outcome of a misalliance" ("Meine Existenz sey die Wirkung eines Mißbündnisses" [3]). She relegates her biological parents to nothing more than a mistake, a "misalliance," that assumingly she is glad to be rid of. Judith E. Martin (2011) argues in this vein that Unger eradicates the stability of the genealogical family tradition in order to emphasize instead Mirabella's unique and individualistic personality ("Early Fictional Responses" 108). Furthermore, Mirabella's lack of family correlates to two of Foucault's distinctions of the modern individual (Foucault 42). The first of these is an individualistic attitude, defined as the absolute value of the individual in his or her singularity and independence from the group that he or she used to belong to. In this case, Mirabella can focus on her own self since she is detached from her family. The second distinction is in the intensity of the relations to the self. That is, one should see the self as an object that must be acted upon. Here there is a distinction between Mirabella's self and the pietistic soul, for unlike the Pietist whose original state is already defined (i.e., as sinful), Mirabella sees herself as a blank slate, an object that needs to be crafted and over which she has complete authority.

Having established a certain attitude toward her self, Mirabella begins a program of moral self-cultivation through the spiritual practice of reading that likewise challenges traditional boundaries. This she begins a few days after being adopted when her foster father introduces three French authors to her: Jean de la Fontaine, Peter Corneille and Jean Racine. These works become for her a first education. It is interesting to note that though her adoptive parents are clerics they do not begin her readings in standard pietistic fashion with passages from the Bible or with common prayers and catechisms; as Mirabella explains, "Although [my adoptive father] was spiritual, he was not concerned with religious instruction; for no other reason than he didn't want to place on me certain dogma or formal morals" ("Wie sehr er auch Geistlicher war, so befaßte er sich doch nicht mit der Unterweisung in der Religion; unstreitig aus keinem anderen Grunde, als weil er noch kein bestimmtes Dogma in mich niederlegen wollte" [5-6]). The actions of this foster father immediately deconstruct the traditional authority of the cleric; instead of forcing his daughter to conform, he enables her to become her own individual. 
Mirabella's inclusion that "he was spiritual" affirms his continued interest in morals, but not solely those determined by authoritative, religious institutions. For this reason, Mirabella's adoptive father provides her with a counter-instruction-a set of three French and specifically secular classics, each of which provide their own moral commentaries-and he gives her the freedom to craft from them her own moral code. But not only is this new moral self-cultivation overtly secular, it also strays outside of the confines of what was traditionally considered feminine. Mirabella explains that "this lecture did not yet adhere to those things which constituted the elements of a female education" ("die Lektüre [gehörte] noch nicht zu den Dingen, welche die Elemente einer weiblichen Erziehung ausmachen" [9]). She does not label this education as strictly masculine; rather, she speaks of the feminine in a futuristic form. The reading of these specific texts is "not yet" part of a female education, but through such pioneering endeavors such as her own, it soon will be.

Mirabella's treatment of this French literature is focused and intentional. She describes her approach as follows: "Through my foster father, I became familiar at the age of fifteen with three French authors, who I diligently read and nearly learned by heart" ("So war ich doch durch meinen Pflegevater von meinem funfzehnten Jahre an mit drei französischen Dichtern bekannt geworden, die ich unablässig las und beinahe auswendig lernte" [9]). In the first, her moderation contrasts the stereotypical female figure whose development suffers from reading in excess. ${ }^{\text {viii }}$ More importantly, although these texts are secular, Mirabella reads them through the pietistic lens of introspection. Not only is her reading limited to three authors, but she is close to having their works memorized. Mirabella turns the books she reads into a spiritual practice by reflecting upon the morals presented to her and deciding from them which she would like to apply to herself, namely chastity. Mirabella follows this choice with an elucidation of each author. She begins with La Fontaine, whose fables, "endlessly draw me in, because in them a world is contained, in which a youthful mind can lose itself in delights" ("Die Fabeln des erstern zogen mich unendlich an, weil in ihnen eine Welt enthalten ist, worein ein jugendlicher Geist sich nur mit Entzücken verlieren kann" [Ibid.]). Mirabella is attracted to the morals of these fables. In her statement, she even provides a focus to this attraction-it is her "youthful mind" that delights in La Fontaine's world. The kind of morality and thus chastity that she desires is firstly intellectual; it is not governed by sentiment, but rather it is something to be learned, and as Mirabella further argues, "[I]f anyone should believe that I, as a woman, have only found interest in [sentiment], I will confess to them without a doubt that Corneille's [intellect] is as agreeable to me as Racine's sentiment” ("Ob man gleich glauben sollte, da $\beta$ ich, als Frauenzimmer, meine Rechnung nur bei dem letzteren gefunden haben könne, so gestehe ich 
doch ohne Bedenken, da $\beta$ die Stärke Corneille's mir wenigstens eben so zusagte, als die Sentimentalität Racine's" [Ibid.]). Mirabella provides a new gendered discourse on the type of morality available to her sex. Her chastity will have as much intellect as it does emotion. Finally, it is equal to any morality stipulated as specifically masculine. She concludes by stating, "I gave as much preference to a strong mind as keenly as men have" ("Ich gab dem ersteren um des kräeftigen Gemüthes willen [...] im Ganzen Vorzug, wie eifrig auch die Männer" [Ibid.]). Mirabella is pursuing a form of morality equal to that of any man, and not only that, but she is also confident that she has just as much of a chance to achieve it.

However, by the second half of the first letter, Mirabella acquires a new reading list on account of her acquaintance with a man named Moritz. Moritz himself has just returned to Germany from a three-year stay in Italy and to some extent he represents a Goethean figure who has embarked on a bourgeois voyage of development. But while Moritz's budding teacher-student relationship with Mirabella may be a metaphor of Goethe's own influence on Unger, Mirabella is able to cultivate her self far beyond Moritz, who remains a static figure in the novel. Nevertheless, Mirabella's discussions with him on the significance of Italian literature are necessary to furthering her moral self-cultivation, even if just temporarily so. In Moritz's first conversation with Mirabella, he tells her, "I am inclined to only search for true Poesie among the Italians" ("Dennoch bin ich sehr geneigt, die wahre Poesie nur bei den Italiänern zu suchen" [18]). The primacy of his argument is to provide a specific literary discourse. For eight weeks, he lectures to her on three Italian Renaissance writers: Ludovico Ariosto, Torquato Tasso and Battista Guarini. In one of his lessons, he asks, "What creation is contained within that liberated Jerusalem? Which Frenchman can claim to have something similar emanate from him?" "Welche Schöpfung ist in dem befreieten Jerusalem enthalten; und wo ist der Franzose, welcher behaupten dürfte, eine ähnliche sey von ihm ausgegangen?“ [Ibid.]). Poesie, that crucial term within Romantic thought, Moritz argues (in very much the same vein as Goethe), is perfectly reflected in the poetry of the Italians alone. His example for this is not arbitrary. In citing "that liberated Jerusalem,", he references Torquato Tasso's epic poem Jerusalem Delivered (La Gerusalemme liberata; 1575) and in doing so also calls to mind Goethe's play Torquato Tasso (1790), which he composed immediately after his return to Weimar from his Italian journey. Tasso's epic poem, historically and fictionally, elevates the language of sentiment to something that is refined, natural and graceful. That is, it is a poem of heightened emotions. Moritz states further, "I don't want truth, but rather beauty, a conformity with one's self and harmony in the highest meaning of the word" ("Nicht Wahrheit will ich, sondern Schönheit, Übereinstimmung mit sich selbst, Harmonie in der höchsten Bedeutung des Worts" [Ibid.]). The ennobled expression of feeling is 
one that conforms to a certain classical model and which also correlates to a control of the passions. It is this latter point that has a profound impact on Mirabella through the course of her studies and which causes her to expand her definition of morality to include this component. This second concept is significant in highlighting Mirabella's modern pursuit, for its purpose is not, as it is within the Bible, to remove a certain sin, but more so in enlightened terms to eradicate an irrational power within her which refuses to obey reason (Foucault $55)$.

The second letter of the Confessions marks a significant step in Mirabella's moral self-cultivation. While her readings in the first letter are mediated through others, specifically men-first her adoptive father and then later Moritz-in the second letter she begins to choose her own authors and texts and, as such, she begins to independently exercise her spiritual practice. On her own initiative, Mirabella studies literature and language with a fifteen-year-old princess named Caroline at a summer palace for three months. Though the content of these various texts is a repetition, and an affirmation, of what Mirabella has already been learning both in terms of chastity and controlled passions, it is significant that the books she reads here are of her own choosing-from the idylls of the Swiss poet Salomon Gessner to the Spanish poets Boscan and Garcilaso and the Portuguese poet Jorge de Montemayor (51). The text that stands out to Mirabella the most is Montemayor's Diana (1559), a Renaissance novel that celebrates women with the feminine values of purity, chastity, modesty and virginity. It is also through these texts that Mirabella's self begins to transform. She tells Cäsar: "We never tired to read again and again until these books had completely permeated through us... only then would we go back to the summer palace to have lunch and during this time the material within us would spiritualize" ("Wir wurden nicht müde es zu lesen und wieder zu lesen, bis wir ganz Davon durchdrungen waren [...] so kehrten wir in das Lustschlo $\beta$ zurück, wo wir [...] zu Mittag aßen, und uns auf diese Weise selbst das Materielle vergeistigten" [51]). The linking of reflection, eating and spiritualizing is not coincidental, for through these actions Mirabella metaphorically digests, in a way quite similar to an anti-communion, ${ }^{\text {ix }}$ the material she is reading and this digestion symbolizes her successful intake of the moral knowledge that she has hand-picked. Thus, the moment in which Mirabella is able to independently craft her self-both in her choice of reading material and in the application of its literary depictions of morality to her way of thinkingsignifies, like the conversion moment in a pietistic confession, the moment of her transformation.

The narrative then takes an interesting turn. Unlike the Bildungsroman, the Confessions is not structured as an unending journey of education and 
development. Rather, in terms of structure, it reads more like Francke's Curriculum Vitae, in which, after having come to faith, he delineates the "fruit" of his new way of life. ${ }^{\mathrm{x}}$ Mirabella's transformation, i.e., the moment in which she claims to have achieved her unique moral form, occurs almost at the exact middle point of her confessions, acting like a climax. The second half of her letters are comprised of observations and commentaries, proofs really, on the aesthetic arrangement of her morality, how the spiritual and the physical are linked in her newly cultivated self. Mirabella's physicality, however, has been a point of debate within recent scholarship, and there are some who argue that Mirabella is lacking in any kind of physicality. For example, Elisabeth Krimmer (2005) states, "The first part of Mirabella's story focuses all its narrative energy on the dissociation of woman and body. But Unger does not stop at creating a virginal heroine. Rather, all actual and metaphorical ties between the female protagonist and her bodily existence need to be cut" (246). This supposed lack, scholars have argued, reveals how the Confessions is simply following in the footsteps of Goethe's "Confessions;" near the end of the "Confessions," Goethe's "beautiful soul" states, "My soul would think without the company of my body; it regarded the body itself as a being foreign to it, just as one regards clothing" ("Meine Seele ohne Gesellschaft des Körpers dächte; sie sah den Körper selbst als ein ihr fremdes Wesen an, wie man ein Kleid aussieht" [HA 7:415]). There are others, such as Cindy Brewer (2006), who have argued instead that Mirabella does in fact possess a certain physical form, but that it can only be understood artificially, namely in her mode of dress. Once again, the comparison is made between Mirabella and Goethe's "beautiful soul," the latter of which who cares very little for her clothes, at one time giving her entire wardrobe away (HA 7:418), and at another time even enjoying how terrible her clothes look on her (HA 7:399). If this was the case then Mirabella's claimed morality could easily be relegated to the realm of the superficial and the performative. This article disagrees with both arguments: the lack of physicality and the artificial dress. In regard to the latter, Mirabella's fashion is an odd point of departure considering that the Confessions makes but a few references to clothing. More significantly, when Mirabella does bring attention to her own dress, it is not to emulate or in any way correspond to the appearance of the "beautiful soul" but rather to make fun of her poorly constructed artifice; for the little attention given to Mirabella's clothing in the Confessions has more to do with the novel's attempt to challenge the claim that a person's clothes alone reflect his or her essence.

Mirabella instead institutes a new aesthetic program based on physiognomy. She establishes an entire dissertation on the greater connection between the face and a person's character, arguing that she can ascertain the moral state of her own self through her physique. For example, she tells Cäsar in her third letter, "I want to 
make an artistic comment ... The Beautiful is only the result of inner harmony, of a constructed character" ("Ich [will] nur noch eine artistische Bemerkung machen... Die Schönheit als etwas Sichtbares, nur immer das Resultat einer inneren Harmonie ist, die in sich selbst einen Charakter bildet" [81]). In this claim, Mirabella sets up a paradigm in which a well-constructed moral self is made evident through physical manifestations of beauty, whereas its failings conversely result in excesses of the body, such as being made ugly or a degeneration in health. These physiological conceptions are quite unique for late eighteenth-century Germany in that they incorporate both biblical principles and modern conceptions of physiognomy. In the Bible, a person suffered from bodily ills or diseases if his or her soul was impure. This is made particularly explicit in the Old Testament, in which various diseases, such as consumption, fever and inflammation (Deut. 28:22), boils (Exod. 9:8-12) or even death (Jer. 9:20-22; 14:12) was inflicted upon the Israelites whenever they disobeyed God. Conversely, obedience was rewarded with longevity of life (Exod. 20:12). It is to these religious notions of good health that Mirabella incorporates the study of an aesthetically-based physical perfection from ancient Greece, a study espoused by Johann Kaspar Lavater's essays on physiognomy (1775-1778) and Johann Joachim Winckelmann's "Thoughts on the Imitation of Greek Works in Painting and Sculpture" ("Gedanken über die Nachahmung der griechischen Werke in der Malerei und Bildhauerkunst" [1756]). Mirabella reveals her knowledge of these scholars by contending that the physiognomy of the Greeks, more so than either that of the French or the Italians, as made evident in their statuesque figures, provides the best template to assess the moral cultivation of the self, for at the heart of Greek art is "an inner harmony between mind and soul" ("eine innere Harmonie zwischen Gemüth und Geist" [81]). This purity of the physical body alone can confirm a moral integrity of the self. ${ }^{\mathrm{xi}}$ By linking an ideal mode of being and physique, Mirabella argues that a woman should not just exist as a "beautiful soul," but rather she should also have an accompanying beautiful body, prompting her to claim near the end of her confessions, "A beautiful soul can only live within a beautiful body" ("Eine schöne Seele könne nur in einem schönen Körper wohnen" [Ibid.]). ${ }^{\text {ii }}$

For this reason, in her pursuit of moral self-cultivation, Mirabella does not have to make a choice between the development of her mind or her physical body; rather, she sees the cultivation of her self and the care of her body as interconnected. Mirabella only has to regularly assess her facial features and chestnut brown hair in the mirror every morning. This activity, she argues, is not purposeless. She tells Cäsar: "I can assure you with all truth that my frequent visits to the mirror are not spent in vain; this inspection grants me a true image of my self" ("Mit Wahrheit aber kann ich versichern, da $\beta$ mich das öftere Hintreten vor dem Spiegel nicht 
eitel machte; diese Beschauung gewährte mir nur ein Bild von mir selber" [6]). Mirabella uses these inspections to assess the entire trajectory of her moral self, not only its current state but also from whence it has come. The inclusion of her hair in this activity is significant, for, as Lavater argues in his Physiognomic Fragments (Physiognomische Fragmente zur Beförderung der Menschenenntnis und Menschenliebe), a person's hair directly impacts, either positively or negatively, his or her facial features: "A tiny curve or point, a lengthening or shortening, often only by the width of a thread of hair; the most minute displacement or distortion-how noticeably something like this can change a face, the expression of a character trait!"xiii ("Eine kleine Biegung oder Schärfe, eine Verlängerung oder Verkürzung, oft auch nur um die Breite eines Fadens, eines Haares; die mindeste Verrückung oder Schiefheit, wie merklich kann dadurch ein Gesicht, der Ausbruck eines Charakters verändert werden" [143]). Thus the "luxurious growth of her hair" ("die Üppigkeit meines Haarwuchses" [6]) plays a significant role in making her facial features more beautiful. But even where she is not beautiful, Mirabella believes that she is, at the very least, becoming "pretty" ("hübsch" [Ibid.]). Furthermore, throughout her entire life from childhood onward, Mirabella never gets sick. Here then is one of the greatest distinguishing features between Mirabella and Goethe's beautiful soul, namely that while the latter slowly digresses physically throughout her confession, thereby revealing the failings of her self as reflected in the degradation of the body, Mirabella, in contrast, continues to remain a picture of good health (95). In this way, Mirabella's moral self is confirmed.

Finally, having cultivated a specific moral form with an accompanying aesthetic arrangement, Mirabella needs to undergo a testing procedure in order to, using the words of Foucault, move forward in the true acquisition of her cultivated self (58). In typical eighteenth-century fashion, the court is constructed for Mirabella as the site in which to be tested. It is Mirabella's task to live amidst its vices, namely amorality and superficiality, to consider if they have a representation within her own moral self and, if so, to "shake them out" (Ibid., 61). In this way, Mirabella will, as her adoptive father tells her, treat her self like "a diamond being polished" ("was der Diamant durch die Politur erhält" [34]). Interestingly, this notion of being tested also finds its origins in the traditional confession, which describes how a believer must undergo various trials in the outside world in order to make his or her faith genuine. It is only after the religious convert has been "refined through fire" that he or she will be able to rid one's self of sin and thus be made "perfect and complete." ${ }^{\text {xiv }}$ Likewise, Mirabella must struggle within the court, a place that she recognizes exists wholly in contradiction to her newly cultivated moral self (33), in order that she may strip off anything that hinders her from being both chaste as well as in control of her own passions. However, her 
intent deviates from the earlier tradition in that she will both assess and remove faults according to her own rules of conduct as opposed to those more institutionally prescribed. According to this modern self-examination, if faults are identified, Mirabella would not charge her self as being guilty per se, but rather her course of action would be "to determine the rational equipment needed for future, wiser behavior" (Foucault 62).

During Mirabella's time at court, she makes a radical discovery: moral selfcultivation is only possible through a consistent and attentive focus on the self, whereas amorality is the result of a lacking care thereof. She continues to provide an acute diagnosis of the persons of the court, arguing that the root cause of their vices is not a pre-existing sinful state, but rather slothfulness, which leads to boredom, and it is this latter condition that causes various dysfunctions of the self. Mirabella supports this new idea in her analysis of the court's obsession with card playing, of which she states, "[Card playing], which is so often conducted at court, is a pis aller, ${ }^{\mathrm{xV}}$ because it is impossible for this society to keep itself engaged in noble ways, they have found a loophole to not stay completely idle" ("Das Spiel, so wie es am Hofe getrieben wird, ist ein pis aller; weil es unmöglich ist, eine große Gesellschaft auf eine edle Weise in Thätigkeit zu setzen, so hat man diesen Ausweg erfunden, sie nicht ganz unbeschäftigt zu lassen" [36]). From her observation of the court's vices and its causes, Mirabella begins to fortify herself accordingly by assembling a rigid, daily routine. Like her time at the summer residence, she wakes up early every morning, no matter the season; she then washes, gets dressed and conducts various chores (35); the rest of her day is spent reading. ${ }^{\text {xi }}$ The continuation of her spiritual practice during this time is significant for three reasons. First, it enables her to continue meditating on and applying her chosen truths to her self. Second, her rigid routine, of which her reading is a part, prevents her from becoming bored. Third, the timing of her spiritual practice is crucial in that, since it is conducted in the afternoon or evening, she is able to "review the day that had gone by, specifically [her] progress that day" (Foucault 60-61), thereby considering if there had been moments in which she had failed in the care of her self or conversely which vices she had resisted and, in conjunction to this, in what respect she had been made better. It is through this process, through her own efforts, her own constant diligence, that refinement becomes possible.

To this, on account of her time at court, Mirabella comes to represent a champion of middle class morals; for it is in her successful refinement that the moral self she seeks to embody is proven worthy, allowing her to differentiate herself, first, from Goethe's "beautiful soul" and, second, from the prototypical courtly woman in the Confessions, who is not given a first name either but rather is only referred 
to as "Madame Etiquette." The form of Mirabella's self is genuine, whereas both "the beautiful soul" and "Madame Etiquette" exist superficially. The latter two lack, in Mirabella's words, "an inner content" and a "true core" ("innerer Gehalt," "eigentlicher Kern" [34]), the proof of which is found in their inability to create more for their self than just an impression of morality. Mirabella critiques Goethe's "beautiful soul" in that, in her retreat from the court, she never allowed her self to be tested and thus, in contrast to Mirabella, she can never fully measure whether her moral self possesses faults or not. "Madame Etiquette," on the other hand, uses wit and guise, in particular through her recitation of rhymes and verses, in order to elevate her superficial language to an art form. But while she talks in guise, Mirabella conversely speaks only of those truths that comprise her self, thereby reflecting a truer and higher "culture" ("die höhere Cultur" [45]). In other words, while "Madame Etiquette" tries to depict herself as being more virtuous than she actually is, Mirabella's speech perfectly reflects her own morality. Thus, in having Mirabella analyze her motives, assert her virtues, and reject supposedly female faults such as vanity, she comes to embody the tested, virtuous woman. This achievement allows her to become positioned among other fictional women such as Frau Sternheim in Sophie von La Roche's The Story of Young Lady von Sternheim (Geschichte des Fräuleins von Sternheim [1771]) and the Countess in Christian Fürchtegott Gellert's Life of the Swedish Countess of $G^{* * *}$ (Leben der schwedischen Gräfin von $G^{* * *}$ [1746]). Mirabella's bourgeois affinities in fact extend across national borders. Many German scholars argue that the feminine virtues upheld in the Confessions and other German novels around 1800 were taken directly from, or at the very least influenced, by their English and French counterparts. Barbara Becker-Cantarino (2005) argues that Sophie von La Roche's Sternheim is fashioned in the model of Richardson's Pamela, or Virtue Rewarded (1740) and Clarissa, or The History of a Young Lady (1747-1748) as well as Rousseau's Julie, ou la nouvelle Hélö̈se (1761) (12). Judith E. Martin also argues that La Roche integrated elements from both Richardson's and Rousseau's works and, furthermore, that subsequent German women novelists, including Unger, drew not only on Sternheim in the German tradition, but also on the earlier international models of Richardson and Rousseau ("Introduction" 8). Finally, not being a member of the aristocracy, Mirabella is able to illustrate, in the same vein as Lady Sternheim and Clarissa, that nobility is determined by devotion to morality rather than social standing.

Mirabella's moral cultivation of both her mind and her body into a true form by the end of the Confessions points to her ability, as Foucault argues, to rule over her self (68). Foucault states that the goal of modern self-cultivation is a conversion of the self-of epistrope eis heauton-meaning that one has become his or her own master, free of all dependencies and enslavements (Ibid., 65). 
Through this long letter to Cäsar, Mirabella has shown how she crafted her moral self, separate from pre-existing systems of thought as well as without the help of a metaphysical counterpart, the result of which is that she is able to claim that she is an independent individual, deserving of respect. Indeed, Mirabella makes frequent references and ascribes great importance both to her independent individuality as well as her "peculiarity" ("Eigenthümlichkeit" [1]), recognizing how both were not considered proper for a woman. In this way, Mirabella makes herself a new and even more secular example to not only the ideal representation of the pietistic beautiful soul-typically defined as a passive, virtuous woman, leading an introverted life according to biblical precepts-but also to Goethe's "beautiful soul," who though also largely secular in self nonetheless still develops under the direction of men. Mirabella's new image of the beautiful soul serves as the foundation for a more modern understanding of a woman who is in control of her own cultivation, including what she reads, how she applies it to her self and how she subsequently thinks and acts. Finally, her self-mastery allows for her to claim moral authenticity. Her moral self provides an alternative to the superficiality of moral performance while still allowing for subjectivity, an achievement that conveys a sense of self-importance as well as self-satisfaction.

\footnotetext{
${ }^{i}$ See Niggl for one of the most detailed accounts on the history of German autobiographical writing during the eighteenth century. For further references, see both Misch and Steussy.

ii Henceforth cited as Confessions.

iii "HA" refers to the Hamburg edition of Goethe's collected works.

iv For more on the intertextuality between Unger's Confessions and Goethe's "Confessions," see Giesler (11, 55, 73-74) and Zantop (29-32). For further comparison, see Henn and Hufeisen.

${ }^{v}$ See Brewer, Lange, Richards, Schmid and Zantop. These feminist critics, however, widely differ in regard to what exactly Unger revises in her Confessions. For example, Anna Richards (2005) considers the emancipatory potential of the heroine's inner self in order to achieve her own unique individuality (238-239). Cindy Brewer (2005) conversely argues that Unger explores the conditions necessary for the successful individuation of the female artist ("The Seduction of the Beautiful Soul" 47); and Sigrid Lange (1995) examines the difference in the act of writing between Mirabella and Goethe's "beautiful soul".

vi Goethe immediately voiced his disapproval of this new feminine image because he was convinced that Mirabella's development followed a male trajectory. Following the publication of Unger's novel, he wrote in a newspaper article, "We simply see here a manly woman, a woman who thinks like a man" ("sich uns hier wirklich eine Männin, ein Mädchen wie es ein Mann gedacht hat [zeigt];" qtd in: Goethe, Johann Wolfgang von. "Bekenntnisse einer schönen Seele, von ihr selbst geschrieben." Jenaische Allgemeine Literatur-Zeitung 16 July 1806. Nr. 167. P. 105-109). Goethe's concern reflects the way in which Unger's heroine challenged traditionaleighteenth-century gender stereotypes.

vii English translations by Michelle Reyes.

viii The figure of the female who reads in excess is explored in several of Unger's novels. For example, in her first novel Julchen Grünthal (1784), the moral development of the main
} 
protagonist, Julchen, suffers and in fact rapidly digresses when she becomes exposed to a variety of secular texts, which she reads without discernment or reflection.

${ }^{\text {ix }}$ I am grateful to those who attended my panel at the 2013 Aphra Behn Society's biennial conference, "Women, Reputation, and Identity in the Long Eighteenth Century," in Tulsa, Oklahoma. It was during the following panel discussion that the issue of anti-communion was brought to my attention.

${ }^{x}$ The metaphorical correlation between a Christian's actions and the fruit that a tree produces is taken from the biblical passage Matthew 7:15-20.

${ }^{\mathrm{xi}}$ For a further discussion on the purity of the body and moral integrity, see Schmid (98).

xii This is a modification of the famous Latin quotation "mens sana in corpore sano," meaning "a sound mind in a healthy body."

xiii Translations by Michelle Reyes.

${ }^{\text {xiv }}$ These two concepts are taken from the biblical passages James 1:4 and Colossians 4:12.

xv "Pis aller" is a French phrase used to describe the final resort or, literally, "to go at its worst."

${ }^{x v i}$ During her time at court, Mirabella continues to be strict in choosing her reading material. She only wants to read books that pertain to her moral self-cultivation; any book considered "amoral" is rejected. For this reason, she refuses to read the works of Shakespeare because, she argues, matters of femininity, including chastity, are curiously missing. She argues, "Shakespeare only wrote for men; reading either his tragedies or his comedies for women will do as much good as riding a horse" ("Shakspear hat nur für Männer geschrieben, und Weiber, welche seine Trauerspiele und Lustspiele mit Vergnügen lesen, verderben nichts mehr an sich selbst, wenn sie Pferde reiten" [10]). While an argument could be made for the immorality present in Shakespeare's works, it is most likely that this rejection of Shakespeare has more to do with Unger's rejection of Goethe, who avidly read and advocated for his works, than an aversion to the works of this English playwright.

\section{Works Cited}

Becker-Cantarino, Barbara. "Introduction." German Literature of the Eighteenth Century. The Enlightenment and Sensibility. Ed. Barbara BeckerCantarino. Rochester, NY: Camden House, 2005. Print.

Brewer, Cindy P. “'Beautiful Souls' and 'Misfashioned Sons': Raphael's Transfiguration in the Context of Friederike Helene Unger's Bekenntnisse einer schönen Seele von ihr selbst geschrieben." Women in German Yearbook 21 (2005): 103-33. Print.

---. "The Seduction of the Beautiful Soul: Anxiety of Influence in Friederike Unger's Bekenntnisse einer schönen Seele von ihr selbst geschrieben." Monatshefte 98 (2006): 45-67. Print.

Foucault, Michel. The Care of the Self. New York: Random House, 1986. Print.

Giesler, Birte. Literatursprünge. Das erzählerische Werk von Friederike Helene Unger. Göttingen: Wallstein, 2003. Print. 
Goethe, Johann Wolfgang von. Goethes Werke. Hamburger Ausgabe. Vol. 7. Ed. Erich Trunz. Hamburg: Christian Wegner Verlag, 1981. Print.

Henn, Marianne and Britta Hufeisen. "Bekenntnisse einer schönen Seele aus weiblicher Sicht. Friederike Helene Ungers Roman." Frauen:

Mitsprechen. Mitschreiben. Beiträge zur literature- und sprachwissensschaftlichen Frauenforschung. Ed. Mariane Henn and Britta Hufeisen. Stuttgart: Heinz Verlag, 1997. 48-68. Print.

Krimmer, Elisabeth. "German Women Writers and Classicism." The Camden House History of German Literature. Vol. 7: The Literature of Weimar Classicism. Ed. Simon Richter. Rochester: Camden House, 2005. 237-64. Print.

Lange, Sigrid. "Die Wirklichkeit der Kunst: Friederike Helene Ungers 'Bekenntnisse einer schönen Seele.'" Spiegelgeschichten: Geschlechter und Poetiken in der Frauenliteratur um 1800. Frankfurt a.M.: Helmer, 1995. 42-70. Print.

Lavater, Johann Kaspar. Physiognomische Fragmente, zur Beförderung der Menschenkenntniß und Menschenliebe. 1775-1778. Stuttgart: Reclam, 1984. Print.

Martin, Judith E. "Early Fictional Responses. Politics, National Identity, and Gender in the Novels of Karoline Paulus and F.H. Unger." Germaine de Stäel in Germany: Gender and Literary Authority (1800-1850). United Kingdom: Fairleigh Dickinson UP, 2011. 79-122. Print.

---. "Introduction." Germaine de Stäel in Germany: Gender and Literary Authority (1800-1850). United Kingdom: Fairleigh Dickinson UP, 2011. 1-28. Print.

Misch, Georg. Geschichte der Autobiographie. Berlin: Teubner Verlag, 1931. Print.

Niggl, Günter. Geschichte der deutschen Autobiographie im 18. Jahrhundert. Theoretische Grundlage und literarische Entfaltung. Stuttgart: Metzler, 1977. Print. 
Richards, Anna. "The Era of Sensibility and the Novel of Self-Fashioning." German Literature of the $18^{\text {th }}$-Century: The Enlightenment and Sensibility. Ed. Barbara Becker-Cantarino. Rochester, NY: Camden House, 2005. 223-44. Print.

Schmid, Sigrun. Der "selbstverschuldeten Unmündigkeit” entkommen:

Perspektiven bürgerlicher Frauenliteratur. Dargestellt an Romanbeispielen Sophie von La Roches, Theres Hubers, Friederike Helene Ungers, Caroline Auguste Fischers, Johanna Schopenhauers und Sophie Bernhardis. Würzburg: Königshausen \& Neumann, 1999. 93-117. Print.

Stephan, Inge. 'Das Konzept der 'schönen Seele:' Zur geschlechtlichen Codierung einer philosophisch-religiösen Figuration im Gender-Diskurs um 1800 - am Beispiel der Bekenntnisse einer schönen Seele von Goethe (1795/96) und Unger (1806).“ In Askese, Geschlecht und Geschichte der Selbstdisziplinierung. Ed. Irmela Marei Krüger-Fürhoff and Tanja Nusser. Bielefeld: Aisthesis Verlag, 2005. 55-70. Print.

Steussy, Fredric S. Eighteenth-Century German Autobiography. The Emergence of Individuality. New York: Peter Lang, 1996. Print.

Unger, Friederike. Bekenntnisse einer schönen Seele von ihr selbst geschrieben. 1806. Hildesheim: Georg Olms, 1991. Print.

---. Julchen Grünthal. Eine Pensionsgeschichte. Mit allergnädigsten Freiheiten. Berlin: Johann Friedrich Unger, 1784. Print.

Zantop, Susanne. "The Beautiful Soul Writes Herself: Friederike Helene Unger and the "Große Göthe.'" In the Shadow of Olympus: German Women Writers around 1800. Ed. Katherine R. Goodman and Edith Waldstein. Albany: New York UP, 1992. 29-51. Print. 
ABO: Interactive Journal for Women in the Arts, 1640-1830, Vol. 4 [2014], Iss. 2, Art. 1 